Annales Missiologici Posnanienses t. 19 (2014), s. 107-135

DOI: $10.14746 / \mathrm{amp} .2014 .19 .5$

ROBERTO CATALANO

Facoltà di Missiologia, Pontificia Università Urbaniana, Roma

\title{
Missionary Societies in the Evangelical Churches. Origins and Characteristics
}

\footnotetext{
"This Protestant form of association - free, open, responsible, embracing all classes, both sexes, all ages, the masses of the people - is peculiar to modern times, and almost to our age."1
}

The present study is an attempt to describe the phenomenon of missionary societies within the Evangelical Churches. Their appearance took place between the end of the $18^{\text {th }}$ and the beginning of the $19^{\text {th }}$ centuries. It is, indeed, surprising how little attention these societies have attracted in studies of the $19^{\text {th }}$-century Church mission, considering the impact they had on Western Christian faith and the role they played in the transformation of world Christianity. In the following pages we focus on the historical aspects and on some of the main features of these societies, which brought an important contribution to the missionary movement as a whole.

\section{Introduction}

\subsection{The Great Awakenings}

The origins of modern voluntary societies have to be traced to the end of the $18^{\text {th }}$ century. At the beginning of the new century, they spread widely across the world and in the last century developed new missionary projects and per-

${ }^{1}$ To Advance the Gospel: Selections from the writings of Rufus Anderson, ed. R. Pierce Beaver, Grand Rapids 1967, p. 65; A.F. Walls, The Missionary Movement in Christian History. Studies in the Transmission of Faith, Maryknoll 1996, p. 242. 
spectives. They represented an unexpected and unprecedented development in the Evangelical world, as effectively summarized by the American missionary Rufus Anderson: "It was not until the present century that the evangelical churches of Christendom were ever really organised with a view to the conversion of the world." 2 The main context for this process is represented by the two Great Awakenings which took place during the $17^{\text {th }}$ century. Specifically, the Second Awakening, which developed during the American War of Independence, played a decisive role for Protestant missions, which, in the first phase of the Reformation, were rather sporadic, if not absent, due to a series of motivations. ${ }^{3}$ Apart from religious and spiritual aspects, there were other elements, which added significance and impetus to the Awakening. James Cook's travels, for instance, brought new enthusiasm to thousands of people. ${ }^{4}$ Reading his diaries provoked great interest in adventure but, at the same time, gave rise to a new wave of religious enthusiasm. There was a strong feeling that, through the discovery of unexplored lands and unknown peoples, God wished to open new fields to missions. An optimistic attitude towards humanity prevailed all over Europe, thanks also to the Enlightenment, which began to be perceived as a new socio-cultural phenomenon.

Within the spiritual domain, there was a growing experience of God's love, fostered also by John Wesley and the Methodist movement, which perceives God as a God of mercy. Constrained by Jesus' Love is the title of a book which examines the missionary motivation in England during the $18^{\text {th }}$ century. It effectively expressed new feelings within the Churches of the Reformed world. The author, Van Den Berg, outlines how the idea of God's love was an indispensable element and an incentive in the process which fostered missions in

${ }^{2}$ To Advance the Gospel, op.cit., p. 64; A.F. Walls, The Missionary Movement in Christian History, op.cit., p. 241.

${ }^{3}$ The Second Awakening had an unimaginable impact in North America where, in the span of a few years, the affiliation to the different churches doubled after having touched a discouraging $5 \%$ of affiliation during the War for Independence. The phenomenon was not confined to the new continent. Europe also experienced a new wave of religious enthusiasm, especially in England where this phase was called the "Evangelical Awakening." (See D.J. Bosch, Transforming Mission. Paradigm Shifts in Theology of Mission, Maryknoll, 2011 [1 $1^{\text {st }}$ edition 1991], p. 283-284).

${ }^{4}$ Captain James Cook (1728-1779) was the British explorer protagonist of three journeys to the Pacific Ocean. He was the first European to touch the eastern coast of Australia and even reached the Hawaii islands. After fighting in the Seven Year War and the siege of Quebec, he engaged in travelling, exploring and designing carts. He died in the Hawaii islands. For a complete bibliography, see. P. Aughton, Endeavour: The Story of Captain Cook's First Great Epic Voyage, London 2002; J. Cook, The Journals, ed. P. Edwards, London 2003; idem, A Voyage Round the World, ed. G. Forster, vol. 1-2, University of Hawaii Press, 2000 (published first 1777 as: A Voyage round the World in His Britannic Majesty's Sloop Resolution, Commanded by Capt. James Cook, during the Years, 1772, 3, 4, and 5); R. Hough, Captain James Cook: A Biography, London 1994; J. Robson, The Captain Cook Encyclopedia, Random House Australia, 2004; N. Thomas, The Extraordinary Voyages of Captain James Cook, New York 2003. 
this period. ${ }^{5}$ In fact, Christians of different Reformed Churches, to the sense of gratitude for the gift of the spiritual experience of the awakening, added the impelling desire to share it with others, considered as brothers and sisters. They believed they were contributing to their salvation. For this, those ready to travel overseas were ready to endure anything. A strong ascetic dimension characterized this new phase: the Lutheran theologian Christian Blumhardt greeted the first missionaries of the Basel Mission by reminding them that missionaries should be "friendly, humble, patient ... never boastful nor conceited, nor rude, never selfish, not quick to take offense."

It is in this context of renewed enthusiasm that two important novelties, deeply interconnected, made their appearance: the Missionary Societies and voluntarism. The classic Calvinistic period had been marked by the theological concept of God's sovereignty. This implied that only He could take the initiative to save souls, being the One to reveal the Truth to those He wished. As a consequence, it was necessary to submit completely to God and to his plans. This fostered an attitude of passivity; mainstream reformed theology considered the Great Mandate limited to the apostles and, therefore, concluded. The Second Awakening offered an alternative to this perspective. Those who were touched by God's love and the enthusiastic wave following this experience were not ready to wait for direction by theologians or Church authorities. ${ }^{7}$ Individuals started taking the initiative, out of personal choice, eventually creating societies. The Christian locus was no longer the Church or the State but small groups of individual Christians who voluntarily took on themselves the responsibility of preaching the Gospel to those who did not know it. New, spontaneous, free, and self-supporting associations formed. Faced with this new enterprising spirit, which saw the person man, on one side, as a protagonist and, on the other, as a privileged object of interest, the traditional main-stream Churches remained rather lethargic and passive. For their part, the commercial companies (the East India Company, the West India Company and the Dutch East India Company) had interests in keeping missionaries far from their commercial territories. Missionary enthusiasm, in fact, could damage their profits overseas.

${ }^{5}$ See S.B. Bevans, R.P. Schroeder, Constant in Context. A Theology of Mission for Today, Quezon City-Bangalore 2004, p. 230.

${ }^{6} \mathrm{~K}$. Rennstich, The Understanding of Mission, Civilization and Colonialism in the Basel Mission, in: Mission Ideologies in the Imperialist Era, ed. T. Christensen, W.R. Hutchinson, Aarhus 1982, quoted in: D.J. Bosch, Transforming Mission, op.cit., p. 293.

${ }^{7}$ This had been the attitude suggested by Voetius, who had insisted that the agent of missions could be only the official Church in one of its expressions: the Council, local Synods or the ministers. (See J.A.B. Jongeneel, Voetius'zendingtheologie, de eerste comprehesieve protestantse zendingtheologie, p. 129, quoted in: D.J. Bosch, Transforming Mission, op.cit., p. 335). 


\subsection{The early Missionary Societies: their birth, goals and mission}

A shy preliminary to the vast phenomenon of the missionary societies had already taken place in the middle of the $17^{\text {th }}$ century when the New England Company (NEC) was established by a decision of the British Parliament (on $27^{\text {th }}$ July 1649) ratified by a Royal Charter in 1662 . One of the main goals of the Company was to propagate "Christ's Gospel among the pagans of New England and of the neighbouring area in America." To fulfil this mission the Company sent missionaries and teachers to New England, to Virginia and to New York, as well as to the West Indies and to British North America. ${ }^{8}$ Contemporary to the first efforts by the NEC, John Eliot, a Presbyterian, preached the Gospel to natives in a territory which corresponded to the present State of Massachusetts, where he established what he called Praying Churches. Eliot authored a translation of the Bible in the Algonquian language and contributed towards the establishing of the Society for the Propagation of the Gospel in New England (1649), which preceded the foundation of the Society for the Propagation of the Gospel in Foreign Parts (SPG) in 1701. This society was destined to have a remarkable impact as its aim was the pastoral care of the "subjects" of the Crown in the territories under its control. The SPG committed to provide bishops and pastors who could revive the faith, ensuring a political and social balance in the overseas territories. ${ }^{10}$ The Society had the Archbishop of Canterbury as its head, in this way maintaining an Anglican, Episcopal character. Nevertheless, only one third of the SPG missionaries were British, while a good number were "strangers within the realm" - from Wales, Ireland and Scotland - as well as from other European Protestant communities: Germany, Holland, Piedmont, and Switzerland. ${ }^{11}$

A third society was established before the end of the $17^{\text {th }}$ century, the Society for Promoting Christian Knowledge (SPCK). Its aim was "to improve the intellectual, spiritual and material conditions of those outside the salutary

${ }^{8}$ Though the initial idea was to promote evangelization and education in local languages, due to difficulties in recruiting suitable personnel, the NEC had to implement its project in English. Moreover, in order to ensure easy access to education, it was planned to relocate the native population and settle the people around the schools and churches.

${ }^{9}$ The term "subjects" meant much more than simply British emigrants and settlers in North America. Though the Charter does not mentioned indigenous people and black slaves, the early Instructions for the missionaries suggest to approach, through natural religion, "Heathens and Infidels." In the process the term "native" became inclusive of the indigenous people and of the slaves coming from Africa. See A. Porter, Religion Versus Empire? British Protestant Missionaries and Overseas Expansion, 1700-1914, Manchester 2004, p. 18.

${ }^{10}$ See ibidem, p. 20.

${ }^{11}$ See ibidem, p. 26. 
influence of English education." 12 In reality, the SCPK intended to assist and support other organisations and Church initiatives with the distribution of fundamental Christian literature: the Bible, the New Testament and the Book of Common Prayer. Keeping its activities circumscribed, the SCPK also tried to keep itself out of theological controversies which could have damaged or jeopardized its main goals. When its founder, Thomas Bray, realised the need for instructors and ministers, a request was addressed to the King in order to obtain the establishment of a sister organisation to fulfil this purpose. Though the SPG priorities were, in 1702, "to settle the State of Religion as well as may be among our own people there [...] and then to proceed to the best Methods [...] towards the conversion of the natives," 13 the SPG soon opted to pay greater attention to the conversion of native populations, though this was not in conformity with the original aims and goals of the founding members. ${ }^{14}$

With these societies and their respective commitments to preach to indigenous Americans, that which characterised later missions came into evidence: the necessity to communicate the cultural and human richness of western society, especially of England. The different types of schools - Charity Schools, Sunday Schools - established thanks to the commitment of the members of these initial societies, all aimed at transmitting western cultural patrimony which was considered a "blessing" to be shared with other peoples, who were considered rough and ignorant and usually tagged as "heathens." From the beginning, spirituality and education together were the concern of missionaries from the Reformed Churches. Both of these societies (the SPG and the SPCK) were established by Royal Charter and deeply connected to the institutional Churches. They had strong links with the episcopacy of the Church of England. They tried to commit to a typical church activity: the adequate formation and timely ordination of the clergy. Some of these newly-ordained ministers were sent overseas, but this was practically limited to North America to safeguard the colonies from the threat of the Presbyterians. ${ }^{15}$ Undeniably, in the $18^{\text {th }}$ century, the SPG had a central role in the spiritual and religious develop-

${ }^{12}$ B.K. Pennington, Was Hinduism Invented? Britons, Indians, and the Colonial Construction of Religion, Oxford 2005, p. 27.

${ }^{13}$ R. Wills, SPG Anniversary Sermon 1702, p. 18-19, quoted in E. Pennington, The SPG Anniversary Sermons 1702-1783, n.p., n.d., p. 12 - see B. Pennington, Was Hinduism Invented?, op.cit., p. 28.

${ }^{14}$ Ibid.

${ }^{15}$ SPG had its own specificity, which could have even appeared contradictory. On one side, in fact, this society was lawfully incorporated and had, as its own head, the Archbishop of Canterbury, with a group of vice-presidents chosen among Anglican bishops. As an incorporated society, the SPG had the right to acquire properties as well as to collect funds to support overseas activities. On the other side, subscriptions, collections and commitment of unpaid time ensured that the society could keep a somehow voluntary approach. See A. Porter, Religion versus Empire?, op.cit., p. 17. 
ment of the American colonies of Great Britain. ${ }^{16}$ Nevertheless, notwithstanding efforts to give a wider connotation to the term "subjects," by including colonists and migrants, the society never approached indigenous Americans or the African people in North America, devoting its attention to the white colonial population and, at the same time, concentrating its missionary efforts in establishing the Anglican Church in a secure and systematic way. While ensuring an adequate presence of Anglican bishops and ministers in an effort to minimize the spread of other Christian denominations such as the "Dissenters," the SPG also played an important role as a balancing factor between a good administration, social order and religious affiliation. ${ }^{17}$

\section{The new missionary societies}

\subsection{The Baptist Missionary Society}

The real intuition regarding missionary societies and the role of "volunteers" came with William Carey, a British Baptist, who in 1792 authored a small booklet - An Enquiry into the Obligations of Christians, to Use Means for the Conversion of the Heathens - which was destined to change the missionary approach for evangelical Churches in the $19^{\text {th }}$ century. Carey was also among the founders of the Baptist Missionary Society (BMS). His contribution to the missionary movement is so important that for a long time the British shoe-maker turned Baptist missionary was considered the "father" of Protestant missions. In the last part of his booklet, Carey tried to propose means for preaching the Good News to people who did not have any contact with Christ. He felt that the "Great Mandate" had not ended with the apostles and new methods had to be discovered in order to fulfil it in the present. Well aware that something concrete and definite had to be found, Carey did not draw inspiration from the earlier religious societies (the SPG and the SPCK) but turned his eyes towards the commercial activities of the East Indian Company which had proved itself capable of creating a well-established world network for trade.

When a trading company have obtained their charter they usually go to its utmost limits; and their stocks, their ships, their officers and men are so chosen, and regulated, as to be likely to answer their purpose; but they do not stop here, for encouraged by the prospect of success, they use every effort, cast their bread upon the waters, cultivate friendship with everyone from whose information they expect

${ }^{16}$ See J. Butler, Awash in a Sea of Faith: Christianizing the American People, CambridgeLondon 1990, p. 34, quoted in: A. Porter, Religion Versus Empire?, op.cit., p. 17.

${ }^{17}$ See A. Porter, Religion Versus Empire?, op.cit., p. 17. 
the least advantage. They cross the widest and most tempestuous seas and they encounter the most unfavourable climates; they introduce themselves into the most barbarous nations and sometimes undergo the most affecting hardship. ${ }^{18}$

Christians ought to act in the same way, Carey argues. Their greatest interest should be that of spreading God's kingdom. From this Carey developed his idea to form a society with deeply committed people who could entirely offer their lives to the cause of fulfilling the call of the "Great Mandate."

Suppose a company of serious Christians, ministers and private persons, were to form themselves into a society, and make a number of rules respecting the regulations of the plan, and the persons who are to be employed as missionaries, the means of defraying the expenses. ... This society must consist of persons whose hearts are in the work, men of serious religion, and possessing a spirit of perseverance; there must be a determination not to admit any person who is not in this description, or to retain him longer than he answers to it. ${ }^{19}$

As trade requires structures and infrastructures for success in different parts of the world, Carey was convinced that mission for the Kingdom of God needed societies of the same type, founded and managed by lay people or ministers and established with statutes and regulations. The Baptist Missionary Society (BMS) was established on $2^{\text {nd }}$ October 1792 in the presence of 13 founding members. ${ }^{20}$ The specific goals of the newly-founded society was to collect funds in order to send and to support missionaries overseas and, above all, to invite volunteers for the missions. A month after establishing the Society, an amount of money was already collected. The third meeting decided to open a mission in Bengal not far from Calcutta. ${ }^{21}$ Carey himself was the first missionary, the pioneer of the Serampore Mission. Later, he was joined by two colleagues: John Marshman with his wife Hannah and William Ward.

\subsubsection{The theological foundation of the Baptist Missionary Society}

The famous missiologist and missionary Andrew Walls clearly states that "there never was a theology of the voluntary society $[. .$.$] men of high theo-$

${ }^{18}$ W. Carey, An Enquiry, into the Obligations of Christians, to Use Means for the Conversion of the Heathens, London 1961, p. 78.

${ }^{19}$ W. Carey, An Enquiry, into the Obligations of Christians, op.cit., p. 82.

20 The founding act was held in one of the stronghold of British Baptists, Kettering in Northamptonshire. Carey was not present, because he could not afford to pay the amount required to be a founding member of the Society.

${ }^{21}$ The city of Calcutta, capital of Bengal and one of the largest cities in the Indian sub-continent, at the end of the $20^{\text {th }}$ century, has been renamed Kolkata by the Indian Government in 2001 . 
logical and ecclesiastical principle were often the enemies of the missionary movement." 22 Still, it may be important to highlight some theological background.

Untheological development as it may have been, the voluntary society had immense theological implications. It arose because none of the classical patterns of Church government, whether Episcopal, Presbyterian, congregational, or connexional, had any machinery to do the task of which the missionary societies came into being. By its very success, the voluntary society subverted all the classical forms of Church government, while fitting comfortably in none of them ${ }^{23}$.

In September 1785, Carey, still a young and inexperienced Baptist minister, had the courage to submit to a group of senior Baptist ministers the problem of the validity of the "Great Mandate" till the end of times. He proposed to examine every Christian's duty to spread the Gospel to the nations where it was not yet known. John Collett Ryland, destined to become one of the founding members of the BMS, opposed him vigorously: "Certainly nothing could be done before another Pentecost, when an effusion of miraculous gifts, including the gift of tongue, would give effect to the Commission of Christ as at first ... he was a miserable enthusiast for asking such a question." 24

The conclusion of that exchange between Carey and Ryland became famous: "Young man, sit down," Ryland's said to the young pastor. "When God pleases to convert the heathens He will do it without your aid or mine." ${ }^{25}$ The dialogue contains much of a long theological controversy against the Catholic perspective regarding the availability of redemption to all men and the validity of the apostolic mandate for all times. On one side, the Particular Baptists, on the basis of a hyper-Calvinistic perspective, were convinced that election was a divine and absolute decree. As a consequence, only those who were elected could be saved: Christ died only for those who were chosen and these were the ones who could repent, convert and believe. ${ }^{26}$ The Arminians, on the other side, were convinced of the universal dimension of the redemptive

${ }^{22}$ A.F. Walls, The Missionary Movement in Christian History, p. 246.

${ }^{23}$ Ibid., p. 247.

${ }^{24}$ J.W. Morris, Memoir of the Life and Writings of the Rev. Andrew Fuller, London 1816, p. 96-97, quoted in B. Stanley, The History of the Baptist Missionary Society 1792-1992, Edinburgh 1992, p. 7.

${ }^{25}$ J.C. Marshman, The Life and Times of Carey, Marshman and Ward, vol. 1, p. 10, quoted in: T. George, Faithful Witness: The Life of William Carey, Birmingham 1991 ( $2^{\text {nd }}$ ed. Christian History Institute, 1998), p. 53.

${ }^{26}$ G. Nuttal, Northamptonshire and the Modern Question: A Turning Point in Eighteenth-Century Dissent, "Journal of Theological Studies" 16.1 (1965), p. 102, quoted in: K.J. Stewart, Restoring the Reformation. British Evangelicals and the Francophone 'Réveil' 1816-1849, [Studies in Evangelical History and Thought], Carlisle 2007, p. 13. 
mission of Christ. ${ }^{27}$ In the first half of the 17 th century, Andrew Fuller, ${ }^{28}$ taking inspiration from J. Edwards' Inquiry into the Freedom of the Will, committed to explore the possibility of harmonising the evangelical breakthrough with the Calvinism. He reached the conclusion that there was no contradiction between the sovereign decision of God to save those whom He had chosen and the universal obligation to believe in Jesus Christ on the part of those who heard the Word of God. ${ }^{29}$ His reflections and ideas were published in 1785 as The Gospel Worthy of All Acceptation, where Fuller aimed at recovering the concept of "moral obligation" and "human responsibility," as central elements of a theology of salvation. This was rooted in the conviction that divine sovereignty does not erase the responsibility of believing in Christ once a person received the Good News. ${ }^{30}$ Fuller stated that God's love and man's duty towards Him were the same reality seen from two different perspectives. ${ }^{31}$ These reflections by Fuller opened new ways, leaving behind the extreme Calvinistic thinking, which rejected the possibility that sinners could repent and, eventually, convert. This new perspective offered a doctrinal contribution to the nascent missionary phase.

A second issue was crucial: was the "Great Mandate" still valid? The point was not at all new. Two centuries earlier, Adriano Saravia, had posed the question and, in 1590, he had published De diversis gradibus ministrorum Evangelii, a brief study where he affirmed that Jesus' mandate to the apostles, as expressed in Mt. 28:19, had permanent validity. Carey, therefore, was not, as some claimed, the first Protestant to discuss this issue. ${ }^{32}$ Still, he did it in a context which was entirely different from those who preceded him. Apart from reading the Fathers of the Church, Carey found inspiration from one of Calvin's interpretations of Jesus' mandate to the apostle (Mt. 28:19).

This is just the point of the word go (exeundi): the boundaries of Judea were prescribed to the prophets under the law, but now the wall is pulled down and the

${ }^{27}$ See the New Connection of General Baptists: Articles of Religion (1770), art. 4, in: Baptist Confession of Faith, ed. W.L. Lumpkin, Valley Forge, PA 1969. It may be interesting to notice that, originally, Carey was a follower of the first group, Particular Baptists, who were closer to Calvin's theology of salvation which was closed to the advantages of announcing the Gospel and reaching out, through mission, to those who were still in darkness because they did not know Christ.

${ }^{28}$ Andrew Fuller, a Particular Baptist, was born in Wicken and settled at Kettering. During his life, Fuller pastored two congregations He died on 7 May 1815 at Kettering.

${ }^{29}$ See T. George, Faithfull Witness, op.cit., p. 55.

${ }^{30}$ See B. Stanley, The History of the Baptist Missionary Society 1792-1992, op.cit., p. 6.

${ }^{31}$ Quoted in: T. George, Faithful Witness, op.cit., p. 56-57.

${ }^{32}$ Bosch draws attention to the fact that it is wrong to consider Carey's Enquiry as the earliest example of a Protestant promoting mission by recalling the Great Mandate. Apart from Saravia, J. Heurnius in 1648 and the Lutheran noble Justinian von Welz in 1664 did the same. See D.J. Bosch, Transforming Mission, op.cit., p. 346. 
Lord orders the ministers of the Gospel to go far out to scatter the teaching of salvation throughout all the regions of the earth. ${ }^{33}$

The passage confirmed Carey in his views: the mandate had no temporal limitations. Moreover, he offered three objections in the Enquiry to those who believed that the apostolic office was something exceptional and long since at an end. First of all, if the command had been abrogated the same should have been for the other commands given by Jesus, starting with baptism. All Christian denominations, however, continued to administer baptism and to instruct their followers about the faith. This followed a command given by Jesus, but it was not considered limited to the apostles. Finally, if the assistance promised by Christ himself to those announcing the Good News was limited to the twelve apostles, there would not be any sense in believing in his second promise: His presence till the end of times. ${ }^{34}$ To the theological evidence, Carey added a practical and pastoral experience: the Moravian Brethren. They, in fact, had taken the Gospel to some of the remotest areas in the world (from Labrador to Abyssinia, from the West Indies to North American indigenous populations). The Moravian Brethren had a powerful influence on Carey, both theological and pastoral. The Moravian missions were, in fact, small colonies. They were economically independent, where the Brethren created conditions for the development of handicrafts among the local people. They also promoted agriculture and trade, and they were "very attentive that the bond between the government and the heathen may not in the least suffer by means of evangelicals tenets". ${ }^{35}$

Though Carey found a solution to the theological arguments against the permanent validity of the "Great Mandate," his contemporaries had other, often deeply-rooted ideas which constituted hurdles for a vocation to go towards all people who had not yet heard about Christ. Carey summed them up in the following terms: a false trust in God's Providence worked as a justification for an attitude of inaction; a useless and meaningless prudence while waiting for signs coming from the Spirit and, thirdly, the temptation to believe that there is so much to be done in the land where Christianity had been already preached. ${ }^{36}$ To these objections Carey proposed the example of the apostles, Paul and Silas who, after having been rejected on one side they proceeded in

${ }^{33}$ Calvin's New Testament Commentaries, ed. D.W. Torrance, T.F. Torrance, Grand Rapids MI 1972, p. 221, quoted in T. George, Faithful Witness, op.cit., p. 39.

${ }^{34}$ See W. Carey, An Enquiry, op.cit., p. 9.

${ }^{35}$ A.G. Spangenberg, A Candid Declaration of the Church known by the name of Unitas Fratrum, relative to their labour among the heathen, London 1768, par. 4-5, quoted in: A. Porter, Religion Versus Empire?, op.cit., p. 30.

${ }^{36}$ W. Carey, An Enquiry, op.cit., p. 12-13. 
the opposite direction - and pointed to the work of Catholic missionaries. ${ }^{37}$ As he had done before, he also gave as an example those tradesmen who, for the sake of money, had the courage to risk their lives. ${ }^{38}$

\subsection{Birth and development of missionary societies in the Evangelical Churches}

The BMS opened a new way for mission within the Evangelical Churches. Consequently, in the span of a few years an amazing number of similar associations were established in different parts of Europe and within different Churches. Among the most significant and also the most long lasting societies we can mention The London Missionary Society (LMS, 1795), The Edinburgh and Glasgow Missionary Society (1796), The Netherlands Missionary Society (NMS, 1796), The Church Missionary Society (CMS, 1797), The British and Foreign Bible Society (1804, BFBS), The Wesleyan Methodist Missionary Society (1813) and The Basel Evangelical Missionary Society (1815). Some of these are still active, others have amalgamated, and still others have disappeared. But it is beyond a doubt that they played a unique role in the missionary experience of the Reformed and Evangelical Churches. Though initially characterized by a lack of theological reflection or grounding, they succeeded in a new model of mission, based on the spontaneous and voluntarily association of people, lay and clergy, men and women.

... what we see in Missionary, Bible, Tract and other kindred societies, not restricted to ecclesiastics, not to any one profession, but combining all classes, embracing the masses of the people; and all free, open, and responsible ... It is the contributors of the funds, who are the real association ... the individuals, churches, congregations who freely act together, through such agencies for an object of common interest. ${ }^{39}$

These societies progressively filled the vacuum experienced by Reformation Churches due to the absence of already-established congregations. They represented a novelty which initially did not seem to fit any traditional formulas. ${ }^{40}$ In the course of the $19^{\text {th }}$ century - rightly defined as the missionary century for both the Catholic and the Protestant worlds - they developed new ways

\footnotetext{
${ }^{37}$ Called by Carey "popish missionaries."

${ }^{38}$ W. Carey, An Enquiry, op.cit., p. 11.

${ }^{39}$ To Advance the Gospel, p. 65, quoted in: A.F. Walls, The Missionary Movement in Christian History, op.cit., p. 242.

${ }^{40}$ See A.F. Walls, The Missionary Movement in Christian History, op.cit., p. 246-247.
} 
to influence, to support and even to overcome Churches and States. In support of this, in 1837, Rufus Anderson, an American missionary, foresaw the role of these societies as a sign of the times ushering in a new phase of Christianity. Societies, in fact, benefitted a great deal from technological progress and from easier access to different corners of the world. Never before had the logistics of access to the whole world been so easy. ${ }^{41}$ The societies which reached Asia - especially India and China - Oceania and Africa represented a great innovation. Apart from being open to welcoming and employing new clergy and laity for the missions, they were capable of mobilizing a mass movement in the British Isles, Switzerland, the German states, and elsewhere. People, everywhere felt called to involvement in the mission enterprise by financially and spiritually supporting their missionaries overseas, ${ }^{42}$ as well as news and information bulletins, ${ }^{43}$ where letters and diaries from the different missions were regularly published.

\subsubsection{Pastoral methodologies of the missionary societies}

The evangelical missionary societies were instrumental in contributing to a new pastoral methodology which was basically rooted in the spreading of the word of God in tune with one of Reform's main principles: sola scriptura. Beginning with the Baptist Missionary Society, in 1792, priority was given to translating the Scriptures into local languages. It was a time- and energy-consuming work, which often exhausted the early missionaries. With the translation projects, schools were opened to allow local people to learn how to read and write in order to enable them to study the Scriptures. A third key element was social change, tackled in different ways: developing medical assistance and condemning local practices which the missionary (and the colonizers) considered to be anti-Christian and inhuman, such as sutti in India, where widows cremated themselves in the funeral pyres of their deceased husband. In whatever context, the Societies' missionaries tried to form a local church with native catechists and pastors.

${ }^{41}$ See To Advance the Gospel, p. 59-76, quoted in: A.F. Walls, The Missionary Movement in Christian History, op.cit., p. 241.

${ }^{42}$ See ibid., p. 242.

${ }^{43}$ Walls rightly notes that the role played by the missionary magazines in the birth and development of the Missionary Societies has not received yet due attention from scholars. In fact, the voluntary societies created a new reading public. The abolition of the slave trade, continues Walls, was perhaps the first victory won by modern propaganda methods. For the first time, media were used to educate and mobilize peoples. The first missionary journal was the Mission Register, established in 1812. The circulation of the Register and of other magazines of the moment, was wider that the one of the lay movement, reaching out to all sorts of people in society. See A.F. Walls, The Missionary Movement in Christian History, op.cit., p. 251-252. 
In general, members of the missionary societies felt the urgency to translate the Scripture in order to evangelize the local population but also to help the future pastoral work by local ministers. The translation work, produced in the last decades of the $18^{\text {th }}$ century and in the early ones of the next, was monumental. The missionaries had to learn new languages and, to gain time, they began doing so on the long journey aboard ship before reaching their destination. They authored dictionaries which were simply non-existent before their arrival and even started studies which led, in due course, to the birth of glottology as a science. ${ }^{44}$ It cannot be downplayed the fact that their work, though praiseworthy for the great commitment involved, often showed limitations. Some translations were not accurate enough or they were carried out without a sufficient knowledge of the local languages or they were done with the contribution of local scholars who had no idea of Christianity. Some of them were nevertheless excellent and destined to last. ${ }^{45}$ The main problems were of two types. Firstly, while local scholars ensured that the translation could be understood by local readers, the translators often missed the true meaning of the original text. Secondly, European missionaries, for their part, though fluent in the local language, were not in a position to grasp and to render subtle differences and encountered major problems in making the text comprehensible to those who did not know the original (in Latin or Greek). Alexander Duff in 1839 had to admit:

Notwithstanding the great expenditure of learning and talent, of time and strength and pecuniary resources, there is scarcely one of the twenty or thirty versions into the languages of India, which promises to stand out half a century; or is likely ever to become the standard version in the language. ${ }^{46}$

The second main aspect of evangelical Societies' missionary work was education. The goals were three-fold: to make local people able to read the Scriptures translated into their languages, to form local ministers able to carry out

${ }^{44}$ In the case of BMS, Carey himself managed to master a few Indian languages and for others he relied on local scholars he met while teaching in Calcutta. With their help and of his collaborators - John Marshman and William Ward - Carey completed the translation of the Scriptures into six languages and partially contributed to another twenty-nine. Carey was appointed as professor of Sanskrit and Bengali at Fort William College. There, he met scholars of different Indian languages whom he engaged in translating the Bible though they were Hindus or Muslims who had no idea of Christianity. They would translate the text, while Carey himself, along with Marshman, would revise all the translations, starting from the Greek or Latin texts. See S. Pierce Carey, William Carey, quoted in: E. Daniel Potts, British Baptist Missionaries in India 1793-1837, Cambridge 1967, p. 79.

${ }^{45}$ We refer in a special way to the one in Urdu by Henry Martin. Completed in 1810, it is still authoritative. See S. Neil, A History of Christian Missions, New York 1994, p. 216.

${ }^{46}$ A. Duff, India and Indian Missions, Edinburgh 1839, p. 386, quoted in: E.D. Potts, British Baptist Missionaries in India 1793-1837, Cambridge 1967, p. 86. 
the mission and, thirdly, to favour the civilizing of the "heathens." An example is the London Missionary Society, which opened its Missionary Academy for training volunteers in 1825 . The Society was convinced that "education and the [printing] press are the two great means, which in connection with preaching, will bring about the moral revolution of the world." 47

If schools and bibles have been found to be the engines of civilisation to the people of Britain it is altogether a fair and direct exercise of induction when these schools and bibles are counted upon [...] as equally powerful engines of civilisation to the people of other countries. ${ }^{48}$

The priority assigned to education in the evangelical mission strategy was already evident in the BMS, ${ }^{49}$ whose goal was to educate and form native people to preach the Good News, because foreign missionaries were too few and the costs involved in sending and in supporting them overseas were too high. ${ }^{50}$ It has been always clear in the first missionary society (the BMS) that schools were to be considered as one of the most effective means of evangelization, instrumental for taking the light of the Gospel to the world. ${ }^{51}$ It is clear that the educational enterprise was never an end in itself. Education and cultural formation aimed ever at evangelization. At the same time, missionaries did have a wider vision: through schools young minds could be influenced by Christian values. There was the conviction that the progress of the divine light had to be gradual.

47 J.A James, Missionary prospects: A sermon the substance of which was delivered (...) at the opening of Hoxton College as a missionary academy, Birmingham 1826, p. 24, quoted in: A. Porter, Religion versus Empire?, op.cit., p. 104.

${ }^{48}$ W.J. Roxborough, Thomas Chalmers and the Mission of the Church With Special Reference to the Rise of the Missionary Movement in Scotland [unpublished Ph.D. thesis, Aberdeen, 1978], p. 298, quoted in: A. Porter, Religion versus Empire?, op.cit., p. 106.

${ }^{49}$ The Serampore Trio in 1805 drafted an important document which had to serve as a missionary principles statement. The document - The Form of Agreement - was meant to ensure that the mission could move in the right direction. It was the fruit of years of experience in the field and an attempt to answer the need for a strategy and a methodology to follow. It was, originally, meant to be read daily in Serampore and in all mission station connected with it.

${ }^{50}$ Regarding the controversy which overshadowed the immense work of the Trio, see A.C. Smith, The Serampore Mission Enterprise, Bangalore 2006 and E.D. Potts, British Baptist Missionaries in India 1793-1837, op.cit., p. 114-136. Joshua Marshman and his wife Hannah established and organized local schools according to principles which were drafted in Hints relative to Native Schools, a booklet written and published by Joshua. The first Baptist missionaries had a wide network of schools and their commitment culminated in the establishment of the Serampore College, an enterprise which finally drew off their mental and physical energies and alienated them from the head office of the BMS in England.

${ }^{51}$ Carey himself underlined this to his son Jabez when the later opened the first mission in Amboya. See Brief Narrative of the Baptist Mission in India, London 1819, p. 10, quoted in: T. George, Faithfull Witness, op.cit., p. 143. 
In this connection, in 1829 the Scottish Assembly appointed the Presbyterian Alexander Duff to India in order to implement educational missionary work. The Scottish missionary made schools a privileged way to evangelize and to spread British culture and the English language which became the medium of instruction. He was convinced that in this way Calcutta could be turned into a Christian city within a generation. Education, as a fundamental point of the Reformed and Evangelical missionary strategy, was destined to have a two-edged future. On one side, it succeeded in opening schools all over the world where missionary societies (especially the British) were present. This meant a dramatic increasing in literacy in these countries. For this reason the Reformed and Evangelical Churches were, and today still are widely acknowledged for favouring progress. Missions and schools or colleges became, therefore, almost an identity. At the same time, the educational strategy set in motion a complex process which linked the mission to the colonial administration. Schools and colleges, in fact, especially the ones working in English, appeared to be places to form the "heathens" into Christian believers with a British way of thinking and behaving. This favoured trade interests as it helped to form local people able to work in the administrative cadres of the trading companies. ${ }^{52}$ The weak point of the educational strategy of the missionary societies was the fact that by the end of the first half of the $19^{\text {th }}$ century there appeared a clear connection between Christian missions, Western English-language education and commerce. In fact, by the mid-1850s there were widespread feelings that, due to an overemphasis on English education, converts among the native populations to Christianity were not as many as expected and the involvement of local people in church activities and missions remained limited. In reality, the overconcentration on the city apostolate and on English-language schools deprived the rural areas of missionary work, which should have been carried out in the local languages. ${ }^{53}$ One aspect of this education should not be ignored: the education of girls. Missionary schools, in fact, were instrumental in female education, which was practically absent in the first part of the $19^{\text {th }}$ centuries in the areas reached by the missionary societies. ${ }^{54}$ This was due also to the fact

52 It must be noted that in the Reformed mission schools in India there was a long and even bitter discussion, about the language to be used as a means of instruction. There were three tendencies: those in favour of English (Anglicists), those who preferred the local language, like Bengal for Kolkata (Vernacularists), and even Sanskrit as the root of the north-Indian languages (Sanskritists). After long tensions the so called Anglicists prevailed over the other tendencies, making English language the only medium but creating a reaction which in the end sparked an anti-Christian and anti-Western feeling. See: D. Kopf, British Orientalism and the Bengal Renaissance, Berkeley-Los Angeles 1969, p. 272.

${ }^{53}$ See A. Porter, Religion versus Empire?, op.cit., p. 173.

${ }^{54}$ Among the Hindus, for instance, there was the deeply rooted conviction that a girl who attended school was destined to an early widowhood. Families were also discouraged from sending 
that, often being married, missionaries brought wives who then took care of girls and the education of young ladies..$^{55}$

The third typical activity of the missionary societies is their involvement in social issues. Protestant missionaries very soon got involved in uprooting social evils: slavery, sutti, the caste system, child marriage and the opium-trade. Wherever the first missionaries sent by the societies arrived, they came across social practices which were often unheard of in their homeland. One which initially caused their greatest reactions was the self-immolation of Hindu widows with the deceased husband (sutti). Already in 1799, three years after Carey's arrival in India, we have a description of his reaction to sutti. " ${ }^{56}$ "I was] against what they were doing, telling them that it was a shocking murder. They told me that it was a great act of Holiness, and added in a very surly manner that if I did not like to see it, I would go further off and desired me to go." 57

This was the beginning of a long battle to demonstrate to the local people that sutti was far from voluntary and occasional, as some of the local Brahmins maintained. The Serampore Mission soon tried to make the British administration aware of the problem. The Governors were afraid that interfering in local practices could irritate the Hindu clergy and public opinion in general to the detriment of trade and of Christianity as a religion. It took the missionaries three decades to obtain a final verdict from the British Parliament. The abolition of sutti was passed in 1829 with a Declaration by the Governor General, Lord William Bentinck. The role played by the BMS and other missionaries was crucial in making the act illegal, without nevertheless solving the problem at its very root. ${ }^{58}$

Missionaries Societies were also very active in the anti-slavery movement. Missionaries were well aware that the "transatlantic slave trade, with its degrading of humanity," caused "all talk of the common human need for God

their daughters to any type of school to avoid the danger of vicious men among the teachers. The family was the real centre of life for girls and their formation was entirely in view of their marriage, which was to take place at a tender age. See Second Report of Native Schools, quoted in: E. Daniel Potts, British Baptist Missionaries in India 1793-1837, op.cit., p. 88.

${ }^{55}$ The case of Hannah Marshman in Serampore was significant. After several attempts, in 1825 there were twelve schools for girls with a population of three hundred students. See E. Daniel Potts, British Baptist Missionaries in India 1793-1837, op.cit., p. 122-124; S. Kumar Chatterjee, Hannah Marshman, The first woman missionary in India, Hooghly 2006, p. 79-93.

${ }^{56}$ Carey was significantly sensitive to social issues. Before his departure for India in 1792 he was part of the movement boycotting sugar coming from the West Indies.

${ }^{57}$ From a Letter by Carey to Ryland, Mudnabati, 1 April 1799, quoted in: E. Daniel Potts, British Baptist Missionaries in India 1793-1837, op.cit., p. 144.

${ }^{58}$ Sutti remains a practice among Hindus in certain parts of India. There are still some cases of widows who jump on the husband's funeral pyre. Some are not publicized, but others, e.g. in the $1990^{\text {s }}$, become known shrine or holy site. 
inane and ineffectual." ${ }^{59}$ Thus, missionaries were instrumental in the abolition of the British slave trade in 1807 and in the introduction of the so-called Pious Cause in 1813. The Pious Clause was the important modification introduced into the Charter of the East Indian Company, according to which the Company had to support, from its revenues, a bishopric and three archdeaconries to superintend the British settlements. Missionaries were given freer contact with the local population, which was previously considered illegal and could be punished with deportation to England. In Africa, the missionary movement was clearly associated with the anti-slavery movement. The first centre for Christianity was Sierra Leone where Christians arrived in 1792. Around a thousand people of African birth and their descendents who had fought against their masters in the American War of Independence later reached the African country and brought their respective churches and preachers. A story of the first successful mission was the conversion of the slaves recovered from a ship intercepted while sailing towards North America. From this group came the first missionaries to evangelise other parts of Africa. In general, missions in Africa are to be identified with active humanitarianism. ${ }^{60}$

Later, in 1838, the African Civilisation Society was founded by a member of the Clapham Sect, T.F. Buxton, but it included Baptists, Quakers, Wesleyans and Scottish Presbyterians. Its aim was to redefine humanitarian goals in a more distinctly evangelical form. Buxton was well aware that slavery and criminal seamen were among the causes for the poor inroad of Christianity in Africa and he made proposals and worked to establish conditions for legitimate trade and European models of civilisation. ${ }^{61}$ If this could be achieved, he was convinced, "Africa would present the finest field for the labours of Christian missionaries which the world has yet seen." 62 This point is crucial if we wish to understand how opposition to slavery was different from the opposition to other social evils (such as sutti or child marriages). The battles missionaries engaged in for the promotion of a fitting legislation against slavery, in fact, was considered by evangelicals not only as humanitarian pieces of legislation but as the means by which the Gospel could penetrate areas of darkness. There was a growing awareness among missionaries that, aside from inhuman social issues in local cultures, suffering by natives had been caused by the so-called Christian nations through cruel behaviour. Slavery was the worst among them.

${ }^{59}$ K. Ward, "Taking Stock": The Church Missionary Society and its Historians, quoted in: The Church Mission Society and World Christianity 1799-1999, eds. K. Ward, B. Stanley, Grand Rapids MI 2000, p. 22.

${ }^{60}$ A.F. Walls, The Cross-cultural Process in Christian History, Maryknoll 2002, p. 95.

${ }^{61}$ See A. Porter, Religion versus Empire?, op.cit., p. 150-151.

${ }^{62}$ T.F. Buxton, The African Slave Trade, London $1839^{2}$, p. xi-xii, quoted in: A. Porter, Religion versus Empire?, op.cit., p. 151. 
For this reason the evangelicals remained committed to the antislavery cause throughout the $19^{\text {th }}$ century.

Moreover, many missionary societies, from their beginnings, promoted the medical training of their missionaries before they could leave for overseas. In 1796 the LMS missionaries heading to the Pacific islands already had a medical surgeon among them. Still, the medical mission in a strict sense - i.e., missions basically oriented towards medical practice by missionaries whose primary ministry was medical - came into existence in China. In that part of Asia the strong anti-foreign feeling endangered traditional missionary projects. William Lockhart was the first British medical missionary. He was sent by the LMS to China where in 1843 he established the first hospital. From that moment China and India witnessed a flourishing of medical missions, which in the long run were destined to produce not only excellent hospitals but also leading medical colleges. It has to be noted that, even before a specific medical ministry, evangelical missionaries practised medicine or opened dispensaries in their homes or in makeshift shops in the villages. Some of them were even medically trained, such as Robert Morrison of the LMS, the first official missionary in China, who studied medicine along with the subjects required to be ordained as a minister. In the course of the $19^{\text {th }}$ century the medical missionaries acquired a greater role, distinct from the ordained ministers. Nevertheless, some medical personnel were ordained to carry out the ministerial mission. At a certain stage, there were tensions between the two roles - the ordained and the medical ministers - and the point became one of the most debated at mission conferences. ${ }^{63}$

Though the medical ministry remained the most in view, other lay professions accompanied the missionary societies in their evangelical projects. Among them, teachers were the most numerous and prominent because, as mentioned earlier, of the importance missionaries societies assigned to education. Many missionaries were artisans, such as carpenters, experts in agriculture etc.

\subsubsection{Main characteristics: spontaneity, lay involvement and voluntarism}

In reflecting on the characteristic elements of the missionary societies, it has to be acknowledged that the movement was, first of all, spontaneous. There was never any planning or promotion by the so-called mainstream

${ }^{63}$ A.F. Walls, The Cross-cultural Process in Christian History, op.cit., p. 230. In one of these conferences, held at Shanghai in 1907, Dr. Dugald Christie of the United Free Church of Scotland mission in Manchuria, who was sent as a medical missionary and later also ordained as a minister, presented an interesting paper where he argued that the office of medical missionary is a ministry of the Church that continues the early ministry of Christ. 
Churches. To illustrate this, it may be significant to review how the BMS was established and how the first mission was initiated. William Carey came from humble origins, and after marrying a Baptist, the daughter of a Baptist minister, he himself became a Baptist and, later, was ordained a minister. A decisive element in his formation, apart from the theological preparation, were the books written by Captain James Cook. Through reading them, he came into contact with a world outside England and even Europe. On May 12, 1792, the Baptist pastor published his booklet destined to be the inspiration for the BMS and to change the overall approach towards missions in the Reformed world. Later, in fact, it was defined as "the charter of modern mission with its argument, review, survey and program." ${ }^{.4}$ On October 2 of the same year, the Particular Baptist Society for Propagating the Gospel amongst the Heatens, later renamed the Baptist Missionary Society (BMS), was officially established. BMS had humble and obscure beginnings but the repercussions were unexpected and far-reaching. A few months later, Carey reached Bengal without any kind of preparation and proper planning. Everything was absolutely spontaneous without any inspiration or mandate from Baptist Church authorities.

Later, the CMS, also a voluntary organization, proposed a commitment to Anglican principles and formularies. ${ }^{65}$ This consisted in having episcopallyordained clergy, who originally were not part of the missionary movement. Nevertheless, for quite some time the CMS had to wait for ordained clergy to volunteer for its missions. They had to settle on sending catechists ready to serve as pious laity.

This brings us to the second character of the missionary societies: lay involvement. "The early missionary societies had proved that the missionary vocation could attract numbers of lay volunteers." $" 66$ The early missionaries of the first society, the BMS, were largely lay people, with the exception of William Carey who was an ordained pastor. The same was true for the LMS (established in 1795) which, a year later, managed to send some thirty missionaries to the Pacific. The majority were lay volunteers, often with an artisanal or craft background, married, and ready to leave with their families. Among them, only four were ordained ministers, while one was a surgeon. Different

${ }^{64}$ M.H. Khan, History of Printing in Bengali Characters up to 1966 [unpublished Ph.D thesis, School of Oriental and African Studies, London 1976], p. 218, quoted in: A.Ch. Smith, The Serampore Mission Enterprise, Bangalore 2006, p. 5.

${ }^{65}$ E. Stock, History of the Church Missionary Society: Its Environment, Its Men and Its Work, vol. 1, London 1899 and C. Hole, The Early History of the Church Missionary Society for Africa and the East to the End of AD 1814, London 1896, quoted in: A.F. Walls, The Cross-cultural Process in Christian History, op.cit., p. 223.

${ }^{66}$ A.F. Walls, The Cross-cultural Process in Christian History, op.cit., p. 223. 
and more problematic was the case of the already mentioned CMS, which was established as a voluntary society but with a commitment to Anglican principles. This implied that missionaries to be sent overseas were to be episcopally ordained. The CMS, at least initially, had to come to terms with the fact that no volunteer came from the clergy. The leaders soon understood that it was useless to wait for them and, as a consequence, they started sending lay catechists. ${ }^{67}$ The practice of accepting lay volunteers was so widespread that John Venn, who was long-time Secretary General of the CMS and an acknowledged authority among the missionary societies in general, drafted a memorandum where he drew the attention of the Churches to the practice of the early Christian communities in counting on the role of catechists.

Probably the societies were not interested per se in lay volunteers as such, but rather they tried to tap non traditional sources for ministry. The disappointments led them to attempt to bring the average missionary candidate closer to the general standards expected of the ministry. ${ }^{68}$

The process created a tension between the regularly ordained clergy and lay missionaries. Trying to find a solution to this situation, societies established schools to ensure the training of their missionaries. For some time, the CMS also had to rely on the help of German Pietists formed in the Berlin Seminary ${ }^{69}$ Other societies in the course of the first decades of the $19^{\text {th }}$ century tried to have their missionaries chosen among regularly-trained and ordained ministers but often failed. Significant examples are the missionary societies of Scotland. The written rule that allowed only ordained minister to sail overseas as missionaries could not be observed, because the only volunteers for quite some time were tradesmen or people who had never completed their studies. ${ }^{70}$ Summing up, we can agree with Walls that, "the early missionary societies proved that a missionary vocation could attract numbers of lay volunteers" $"$. For most of the societies the problem remained: how to get missionaries from among the ordained clergy? Later, the CMS set up a college in Islington to make sure that candidates who were not sufficiently prepared could be trained. This institution, on the long run, did succeed in having a remarkable number of students properly trained for mission work. ${ }^{72}$

${ }^{67}$ Ibid.

${ }^{68}$ Ibid.

${ }^{69}$ In the first 16 years of its life the CMS sent 24 missionaries, of whom 17 were Germans already ordained in the Lutheran Church, while of the others only three were ordained.

${ }^{70}$ Ibid., 225.

${ }^{71}$ Ibid., 227.

72 Ibid., 223. 
Closely connected with the lay nature of the early missionary venture of the Reformed Churches, is the role women had in mission work. It was not the result of a strategy but came almost by chance in connection with the lay missionaries (initially all men) leaving for overseas destinations with their wives. Apart from their family role, most of these women also took on missionary work. We have read about Hannah Marshman, wife of Joshua, who, with Ward and Carey formed the Serampore Trio ${ }^{73}$. Women in the different missions became so crucial that they had to be replaced not only at their death, but even whenever they were absent. They succeeded in entering realms - the one of local women - shut to their husband missionaries. Though the role played by women was so vital, nevertheless it took a long time for missionary societies to realise and acknowledge it. ${ }^{74}$

\subsubsection{The missionary societies and colonial administrations}

The rapport between the missionary societies and colonial power would require an in-depth study. Initially, it was not easy. Suffice it to mention the two first Pietist missionaries, Ziegenbalg and Plutschau, who had to spend time in prison after reaching Trequenbar (Tamil Nadu - in India). ${ }^{75}$ In fact, missionaries were unwelcome or supposed to be limited to the overseas personnel coming from Europe. Carey himself landed in Serampore which was a Danish enclave not far from Calcutta but politically safer for missionaries. The norms, dictated by the different trade companies, were originally quite strict; they required missionaries to be expelled when they exercised their ministry outside the ex-patriate community. Still, many of the administrative cadres were practising Christians and never wanted to create problems with missionaries. They often limited themselves to monitoring and checking on the missionary activities. On their part, the missionary societies, after initially unpleasant experiences, started training their missionaries to deal better with the colonial authorities. After the introduction of the so-called Pious Clause in the early $19^{\text {th }}$ century, things improved but the relationship between missionaries (BMS, LMS, CMS) and the administration again became problematic, when Anglicans enjoyed a privileged relationship. In the administration a consider-

${ }^{73}$ Keeping in mind the role of Hannah in managing the house where the missionaries lived and in coordinating the schools opened by them, especially the ones for girls, "the Trio" should have been more correctly named "a quartet."

${ }^{74}$ Interesting contributions to this topic are S. Kumar Chatterjee, Hannah Marshman, op.cit.; D. Robert, American Women in Mission: A Social History of Their Thought and Practice, Macon, GA 1996.

${ }^{75}$ For details on this mission see B. Singh, The First Protestant Missionary to India: Bartholomaeus Ziegenbalg (1683-1710), New Delhi 1999. 
able number of officers were well aware that Anglican missionaries and their activities could contribute to their own advancement. James Buchanan, a wellknown Anglican missionary, had an interesting opinion on this topic.

Let us first establish our own religion amongst ourselves and our Asiatic subjects will soon benefit by it. When once our national Church shall have been confirmed in India, the members of that Church will be the best qualified to advise the state as to the means by which, from time to time, the civilization of the natives may be promoted. $^{76}$

In time, therefore, the administration realised that missionaries could play a key role in the social balance of the overseas territories. The struggle to change or modify the Act regulating the trading companies and the role of the missionaries, however, helped the other Societies to join together ${ }^{77}$ in order to pressure the Government for a new solution. So, the Anglican-trading company relationship brought the Evangelical missions into a more positive relationship with the Government authorities and with each other.

\subsection{The missionary}

It is worth reflecting for a while also on the image of the missionary that emerged from the missionary societies. A text can be taken, once again, from the Enquiry.

The missionaries must be men of great piety, prudence, courage and forbearance; of undoubted orthodoxy in their sentiments, and must enter with all their hearts into the spirit of their mission; they must be willing to leave all the comforts of life behind them and to encounter the hardships of a torrid, or a frigid, climate, an uncomfortable manner of living and every other inconvenience that can attend this undertaking. ... They must be very careful not to resent injuries which may be offered to them, nor to think highly of themselves so as to despise the poor heathens, and by those means lay a foundation for their resentment, or rejection of the gospel. They must take every opportunity of doing them good, and labouring and travelling, night and day, they must instruct, exhort, and rebuke, with all long sufferings, and anxious desire for them, and, above all, must

${ }^{76}$ J. Buchanan, Memories of the Expediency of an Ecclesiastical Establishment for British India, London 1805, p. 20, quoted in: A. Porter, Religion versus Empire?, op.cit., p. 72.

77 The Baptist missionaries were not the only ones to look for a suitable place to start their evangelization. Even the LMS, in 1798 had started by sending to India Nathaniel Forsyth, who found a place at Chinsurah, a small Dutch territory, out of the controlling range of the East India Company. 
be instant in prayers for the effusion of the Holy Spirit upon the people of their charge. ${ }^{78}$

This text clearly sets a very high standard for a missionary to be worthy of the name. Carey himself and his companions could hardly be considered model missionaries. Still, they represented a model for those who followed in their footsteps. What is clear is the importance for the missionary to be absolutely committed to the cause of fulfilling the "Great Mandate" in a world centuries away from the one where Christ assigned it to the apostles. That is why the spiritual dimension has a clear priority over other aspects, as emerges clearly from another paradigmatic text: the sermon delivered by Thomas Haweis on the occasion of the inauguration of the LMS in 1795.

Whom shall we send, and who will go for us? I answer, such as the Lord hath prepared and qualified for the arduous task. Men, whose lives are not dear unto themselves, but ready to spend and be spent in the honourable service. Men, really moved by the Holy Ghost to devote themselves to the work. ... Men, who have an internal evidence of the Spirit, witnessing, with their spirits, that they are the children of God; - a divine ardour, prompting them to prefer the salvation of men's souls to every earthly consideration ... Such are the men the great Shepherd and Bishop of Souls sends, such are the instruments we must seek. ${ }^{79}$

Missionaries emerging from the missionary societies were, at least initially, typical of the "dissenting" world. They appeared to be independent, equipped with an amazing capacity for work, open to learning local languages and cultural traditions but, at the same time, ready to commit themselves against whatever appeared inhuman. Moreover, many of these missionaries were not only lay people, but they practiced skilled trades and, more and more, possessed medical and teaching training and skills. They had only one goal: to preach the Good News to those who had never heard it. In the beginning, often, they were not even sufficiently trained in theology. When, in the course of the $19^{\text {th }}$ century, the missionary societies began by both dissenters and members of mainstream Churches, the issue of an adequate theological formation emerged. A long and, at times, problematic debate also emerged. On one side, mainstream Churches were clear about the fact that none could leave for a mission field without adequate academic and theological training. On the other side, "dissenters" tended to remain open to a more spontaneous missionary ideal. Generally speaking, in the course of the $19^{\text {th }}$ century, all societies

${ }^{78}$ W. Carey, An Enquiry, op.cit., p. 76.

${ }^{79}$ R. Lovett, The History of the London Missionary Society 1795-1895, London 1899, p. 26 ff., quoted in: A.F. Walls, The Cross-cultural Process in Christian History, op.cit., p. 162. 
and Churches worked to ensure that those who volunteered for missions were well prepared for the task awaiting them. ${ }^{80}$ Nevertheless, the evangelical missionary societies had created a new kind of missionary, who, in the decades to come, was destined to have a great influence on the mission world, because they carried a prophetic vision for the future of all of Christianity, including the Catholic Church.

The debate we have just mentioned should not overshadow another aspect of the missionary dimension in the Societies. Though characterized by spontaneity, voluntarism and, often, lack of training, the movement was capable of producing excellent scholars who contributed and gave life to the new sciences of linguistics, indology, anthropology, and tropical medicine. ${ }^{81}$

[Though] the typical missionary long remained a man of humble background and modest attainment, ... many men who would not have been considered for ordination at home, in order to reach the mission field, or in order to be more effective there, set themselves to intellectual effort and acquired learning and skills far beyond anything which would have been required of them in the ordinary run of life. The fact that some of them became legends, and the not less important fact that many displayed the ministerial charismata in a high degree, were to have their own effect in the transformation of the ministry. ${ }^{82}$

\section{Conclusion: mission and collaboration, a pre-ecumenical approach}

The missionary societies brought into the mission experience of the Churches new and unexpected riches, which became the patrimony of many others outside the inner circle of the different groups involved in those Societies (the mainstream Churches and evangelical dissenters). Apart from lay involvement and its voluntaristic wave of enthusiasm or the social involvement, something entirely new, not always fully appreciated, was mutual collaboration. Without ignoring and downplaying tensions due to rivalries, economic strife, or to differences in missionary policies and programs, it has to be acknowledged that a great deal of cooperation characterized the early years. There was mutual esteem, which encouraged each to learn from another's experience of mission. The first Baptists sent to Burma, for instance, were warm-

${ }^{80}$ See A. F. Walls, The Missionary Movement in Christian History, op.cit., p. 161.

${ }^{81}$ An example is given by the early studies of Vedic religions initiated thanks to the efforts and expertise of a group of scholars around Warren Hasting, British Governor in Calcutta. Among them, at the side of scholars such as William Jones, there was also William Carey who, thanks to his knowledge of Sanskrit and Indian languages, contributed a great deal to indological studies.

${ }^{82}$ A.F. Walls, The Missionary Movement in Christian History, op.cit., p. 171-172. 
ly encouraged to contact Catholic missionaries - still considered and called papists - in order to learn about their experiences there. ${ }^{83}$ This spoke of esteem towards Catholic missionaries, but it also spoke of the appreciation of their abilities to develop a missionary strategy. There were also liturgies held in common. While these were dictated by the fact that the respective congregations were too small or even absent, news of these practices sent shock-waves to the respective Churches headquartered in Europe, which never missed an opportunity to caution their missionaries from being too open towards other denominations. The translation of the Scriptures also brought about cooperation among the Societies and even denominations. In time, problems arose due to the quality of the translating work and to the need to collect funds for this purpose. In other words, however, cooperation among the Societies were, at least initially, provoked and fostered by common needs and problems.

The major challenge was harmonising missionary training with the spontaneity of the Societies. In fact, at least initially, most of the missionary societies were born in England or in Scotland, and their operations were mainly in those parts of the world controlled by British trade. Schools and seminaries, however, for the training of missionaries had been established in Germany. Due to the lack of German colonial expansion, these missionaries could only join British mission enterprises. This situation helped to form a collaboration between the two types of institutions: the ones established for training purposes and the missionary societies. ${ }^{84}$ It has been examined how the CMS, created in a well-defined Anglican context, had to accept, at least initially, many Lutheran missionaries. As mentioned above, there were many types of collaboration among the societies and among the missionaries. The SPCK, a typical Anglican institution born a century before the other societies, employed Lutheran missionaries for a long time, especially when operating in the Indian sub-continent. Mutual understanding reached the point that, considering the lack of bishops to ordain indigenous ministers, the British society accepted local bishops ordained by Lutherans in their own rite. As already mentioned, only beginning in 1815 could the CMS ordain Anglican missionaries on regular basis. Until 1850 the CMS was characterized by a Lutheran and Reformed missionaries from Germany and Switzerland and, in a lesser number, from the Netherlands and Denmark. The LMS, on its part, notwithstanding its British

${ }^{83}$ See R. Rouse, William Carey's 'Pleasing Dream', “The International Review of Missions” 38 (1949), p. 189.

Carey himself recommended his son "to find out the present state of the Catholics, and in what way they attempt to make proselytes. ... If introduced to any of the catholic priests, endeavor to procure their confidence, by an ingenuous and affectionate behavior towards them." Periodical Accounts, Vol. III, p. 329-330, quoted in: R. Rouse, William Carey's 'Pleasing Dream', op.cit., p. 189.

${ }^{84}$ See A. Walls, The Missionary Movement in Christian History, op.cit., p. 168-169. 
roots, relied on Scottish missionaries. Rather than a fear of losing one's own identity, the Societies accepted members of other Churches, which showed remarkable mutual trust.

This trend continued for some decades, until the middle of the $19^{\text {th }}$ century. In 1836 there was a split within the Basel Mission between the Lutheran and the Swiss Reformed members. The strife led to the birth of the Leipzing Mission. The Reformed missions began a radical shift: from the conversion of the individual heathens - which represented the goal of most of the societies - to the establishment of local Churches - plantatio Ecclesiae. This new aim pressured the different societies to establish indigenous or local churches as daughter-churches of their own, strictly denominational Church. The mission enterprise as a whole was about to be reshaped. Societies tried to claim territories which would be exclusively Anglican or Lutheran or Baptist, etc. This would characterize Protestant missions from the second half of the $19^{\text {th }}$ century until the end of colonial power.

Closely connected with collaboration among the missionary societies, there is something else to be highlighted: a pre-ecumenical dimension which, probably, represented a prophetic contribution. Ernest Payne at the conclusion of his presentation of the new edition of the Enquiry, published in 1961, states:

The continuing value and appeal of the Enquiry resides in its truly ecumenical spirit and in the fact that it presents in terse and unadorned fashion the gist of the answerable argument that there still rests upon Christians the obligation to use all the means at their disposal for the conversion of unbelievers, wherever they may be. ${ }^{85}$

In brief, Carey's original text contained what could be called a pre-ecumenical attitude characterized by a denominational realism:

I do not mean by this, in any wise to confine it to one de nomination of Christians. I wish with all my heart, that everyone who loves our Lord Jesus Christ in sincerity, would in some way or other engage in it. But in the present divided state of Christendom, it would be more likely for good to be done by each denomination engaging separately in the work, than if they were to embark in it conjointly. There is enough room for all of us, without interfering with each other; and if no unfriendly interference took place, each de nomination would bear good will to the other, and wish and pray for its success, considering it as upon the whole friendly to the great cause of the true religion. ${ }^{86}$

\footnotetext{
${ }^{85}$ E.A. Payne, Introduction, in: W. Carey, An Enquiry, op.cit., p. XX.
}

${ }^{86}$ W. Carey, An Enquiry, op.cit., p. 84. 
Carey, taking into account the great variety and differences between the Churches and missionary groups, suggested to pray one for the other. He was well aware that "many can do nothing but pray, and prayer is perhaps the only thing in which Christians of all denominations can cordially, and unreservedly unite: but in this way we may all be one, and in this the strictest unanimity ought to prevail." 87 The idea of praying for each other is already a significant step, characterized by sincere pragmatism, if we consider the description of the different Churches that Carey himself offers in the first part of the Enquiry. From his analysis of Christianity throughout the centuries, only the Moravian Brethren and the Baptists appear in a positive light. Nevertheless, this reading did not prevent the British Baptist from inviting a collaboration among different groups of missionaries. Missionary societies, therefore, not only recovered the commitment to take the Good News to those who had never heard it, but they considered the possibility of fulfilling the mission together, by collaborating with one another or, at least, by praying for each other. The Enquiry and the Baptist missionaries never spoke of uniting their efforts and their institutions but rather of a collaboration. ${ }^{88}$ Later, Carey went much further ahead with a daring proposal which carried truly prophetic weight. In 1806 he wrote to Fuller, the Baptist theologian and secretary general of the BMS:

Would it not be possible to have a general association of all denominations of Christians, from the four quarters of the world, held there one in about Ten Years? I earnestly recommend this plan, let the first meeting be in the year 1810, or 1812 at furthest. I have no doubt but it would be attended with many important effects; we could understand one another better, and more entirely enter into one others views by two hours conversation than by two or three years epistolary correspondence. ${ }^{89}$

Carey's idea, to organise a world conference at Cape Town was welcomed and admired by Fuller but hurriedly dismissed as a 'pleasing dream.' Nevertheless, we can appreciate Carey's prophetic sensitivity. In his invitation to pray for one another we can easily find signs of what much later became the Week of Prayer for Christian Unity. Furthermore, if his "pleasing dream" had been fulfilled, the Edinburgh Conference held in 1910 could have taken place a century earlier!

${ }^{87}$ Ibid.

${ }^{88}$ See E. Glenn Hinson, William Carey and Ecumenical Pragmatism, "Journal of Ecumenical Studies" 17.2 (1980), p. 73-83.

${ }^{89}$ Letter by Carey to Fuller, Calcutta, May 15, 1806, quoted in: E.D. Potts, British Baptist Missionaries in India, op.cit., p. 53. 


\section{SUMMARY}

The present study attempts to describe one of the most interesting phenomena in the history of missions: the birth and development of the Missionary Societies, which arose between the end of the 18 th and the beginning of the $19^{\text {th }}$ century. The beginning was linked to the humble story of a simple shoemaker, turned Baptist pastor and a missionary in India but it soon developed within all main Churches of the Reformation. Characteristic of the phenomenon was the spontaneity of giving life to societies aiming at preaching the Gospel overseas. It was a novelty in the Reformation world as the missionary venture had found a difficult ground to develop in the first two centuries after Luther and Calvin. These societies were capable in reasonably short time to develop their own pastoral guide-lines and policy and their members in the overseas missions committed themselves to social issues and educational projects as part of the evangelising project. The article examines these elements and other aspects trying to highlight also unavoidable limitation encountered in the process.

Keywords: Missionary Societies, Evangelical Churches, mission methodology, Bible, laity, voluntarism, spontaneity

Słowa kluczowe: stowarzyszenia misyjne, Kościoły ewangelickie, metodologia misji, Biblia, świeccy, woluntaryzm, spontaniczność

\section{BIBLIOGRAPHY}

Aughton P., Endeavour: The Story of Captain Cook's First Great Epic Voyage, London: Cassell \& Co., 2002.

Baptist Confession of Faith, ed. W.L. Lumpkin, Valley Forge, PA: Judson Press, 1969.

Bevans S.B., Schroeder R.P., Constant in Context. A Theology of Mission for Today, Quezon City and Bangalore: Claretian Publications, 2004.

Bosch D.J., Transforming Mission. Paradigm Shifts in Theology of Mission, Maryknoll: Orbis Book, 2011 [ $1^{\text {st }}$ edition 1991].

Carey W., An Enquiry, into the Obligations of Christians, to Use Means for the Conversion of the Heathens, London: The Carey Kingsgate Press Limited (new facsimile edition), 1961.

Cook J., The Journals, ed. P. Edwards, London: Penguin Books, 2003.

Cook J., A Voyage Round the World, ed. G. Forster, vol. 1-2, University of Hawaii Press, 2000 (published first 1777 as: A Voyage round the World in His Britannic Majesty's Sloop Resolution, Commanded by Capt. James Cook, during the Years, 1772, 3, 4, and 5).

George T., Faithful Witness: The Life of William Carey, Birmingham: New Hope Publishers 1991 ( $2^{\text {nd }}$ ed. Christian History Institute, 1998).

Glenn Hinson E., William Carey and Ecumenical Pragmatism, "Journal of Ecumenical Studies" 17.2 (1980), p. 73-83.

Hough R., Captain James Cook: A Biography, London: Hodder \& Stoughton, 1994.

Kopf D., British Orientalism and the Bengal Renaissance, Berkeley and Los Angeles: University of California Press, 1969.

Kumar Chatterjee S., Hannah Marshman, The first woman missionary in India, Hooghly 2006. 
Neil S., A History of Christian Missions, New York: Viking Press, 1994.

Payne E.A., Introduction, in: W. Carey, An Enquiry, into the Obligations of Christians, to Use Means for the Conversion of the Heathens, London: The Carey Kingsgate Press Limited (new facsimile edition), 1961, p. I-XX.

Pennington B.K., Was Hinduism Invented? Britons, Indians, and the Colonial Construction of Religion, Oxford: Oxford University Press, 2005.

Pennington E., The SPG Anniversary Sermons 1702-1783, n.p., n.d.

Porter A., Religion Versus Empire? British Protestant Missionaries and Overseas Expansion, 1700-1914, Manchester: Manchester University Press, 2004.

Potts E.D., British Baptist Missionaries in India 1793-1837, Cambridge: Cambridge University Press, 1967.

Robert D., American Women in Mission: A Social History of Their Thought and Practice, Macon, GA: Mercer University Press, 1996.

Robson J., The Captain Cook Encyclopedia, Random House Australia, 2004.

Rouse R., William Carey's 'Pleasing Dream', “The International Review of Missions” 38 (1949), p. 181-192.

Singh B., The First Protestant Missionary to India: Bartholomaeus Ziegenbalg (1683-1710), New Delhi: Oxford University Press, 1999.

Smith A.C., The Serampore Mission Enterprise, Bangalore: Centre for Contemporary Christianity, 2006.

Stanley B., The History of the Baptist Missionary Society 1792-1992, Edinburgh: T \& T Clark, 1992.

Stewart K.J., Restoring the Reformation. British Evangelicals and the Francophone 'Réveil' 1816-1849, [Studies in Evangelical History and Thought], Carlisle: Paternoster, 2007.

The Church Mission Society and World Christianity 1799-1999, ed. K. Ward and B. Stanley, Grand Rapids MI: William B. Eerdmans Publishing Company, 2000.

Thomas N., The Extraordinary Voyages of Captain James Cook, New York: Walker \& Co., 2003.

To Advance the Gospel: Selections from the writings of Rufus Anderson, ed. R. Pierce Beaver, Grand Rapids: Eerdmans, 1967.

Walls A.F., The Cross-cultural Process in Christian History, Maryknoll: Orbis Books, 2002.

Walls A.F., The Missionary Movement in Christian History. Studies in the Transmission of Faith, Maryknoll: Orbis Book, 1996.

Roberto Catalano - an Italian missiologist, visiting professor at Urbaniana University, Rome (Italy), University Institute Sophia, Loppiano-Firenze (Italy) and Asus (Accademia di Scienze Umane e Sociali), Rome (Italy), holds a Master Degree in Philosophy and Sociology from Università degli Studi di Torino and a doctorate in Missiology from the Urbaniana University in Rome. He lived in India for 28 years where he was actively involved in interreligious dialogue. Since 2008 is the co-Director of the Centre for Interreligious Dialogue of the Focolare Movement in Rome. His recent publications include William Carey e il Trio di Serampore. La missione e i suoi rapporti con l'induismo, Roma: Aracne, 2012. 